\title{
HUMAN IMPACT ON THE PLANT COVER OF FOUR VILLAGES IN SE POLAND
}

\author{
Mągorzata Kotańska, Ewelina Buziak-Chmielowiec, Anna Dąbrowska, \\ Magdalena Gladysz, Aneta Jakielaszek, Tomasz Wójcik
}

\begin{abstract}
M. Kotańska, E. Buziak-Chmielowiec, A. Dąbrowska, M. Gladysz, T. Wójcik, Department of Environmental Biology, University of Rzeszów, Poland, Zelwerowicza 4, 35-601 Rzeszów, e-mail: mkotanska@o2.pl

T. Wójcik, Department of Ecology and Nature Protection, University of Rzeszów, Cicha 2 A, 35-326 Rzeszów, Poland, e-mail: antomi7@wp.pl
\end{abstract}

(Received: March 30, 2015. Accepted: April 28, 2015)

\begin{abstract}
AвSTRACT. The observation of the rapid rate of plant cover transformation caused by urbanization and agricultural technology was the inspiration for undertaking the study in rural areas. The study was carried out in the Sandomierz Basin in four typical villages with varying degrees of the anthropogenic impact. The changes observed included: Koszyce Małe - evident transformation of fields and meadows into building land; Kolbuszowa Dolna - intensive changes in land use, abandonment of fields and meadows, and river regulation; Roźwienica - emergence of new habitats for plant colonization after reclamation of land previously occupied by a brick factory and a landfill; Krzeczowice - intensive crop cultivation and unchanged land use. In 2009-2010, floristic investigations with the patrol method were carried out in these areas. The historical-geographical classification and indices of the anthropogenic changes of the flora were employed in the analysis.

Substantially, domination of synanthropic species over non-synanthropic spontaneophytes was noted in the analysed floras. In the synanthropic species group, the proportion of apophytes was 3-fold higher than that of anthropophytes. Archaeophytes were more abundant than kenophytes. The flora of Krzeczowice, an area affected by long-term anthropopressure, was by approx. $30 \%$ less abundant than that in the other villages; it was also characterised by the highest synanthropization index, apophytization index, and index of apophytism of spontaneophytes. In turn, the flora found in Kolbuszowa Dolna was rich due to the presence of a wide variety of habitats; it was characterised by the lowest apophytization index accompanied by the highest anthropophization index.
\end{abstract}

KEY WORDS: rural areas, Sandomierz Basin, anthropopressure, changes of plant cover, anthropogenic indices

\section{INTRODUCTION}

Intensified processes of natural environment transformations caused by urbanization have focused botanists' attention on changes in urban flora and vegetation. Extensive investigations of synanthropic flora in Poland and Central Europe were initiated in the 60 s of the last century, and they have been continued until nowadays (BOMANOWSKA \& WitOSEAWSKI 2008, BACIECZKO \& BorCZ 2014). The process of synanthropization of the flora in urbanized areas is analysed in detail in temporal and spatial aspects (Jackowiak 1990, Sudnik-WójciKowsKa 1998). Considerably fewer investigations of synanthropic flora have been carried out in rural areas (WoŁKowYckI 1997). Over the last decades, there have been changes in land use and technological changes in agriculture in these areas; villages situated near cities have been undergoing the urbanization process.

The changes observed and the attempt at comparison of urban and rural flora and vegetation initiated by FALIŃSKI (1971), the ongoing investigations of ruderal floras of villages and towns conducted by WOŁKOWYCKI (1997, 2000a, 2000b), and the analyses of the floras of abandoned villages in the Kampinoski National Park carried out by KIRPLUK (1996, 2009, 2011) inspired us to conduct the research of the human impact on the plant cover in rural areas. 
The aim of the study was to explore the human impact on the flora and vegetation in four typical rural localities characterised by varying degrees of anthropopressure.

\section{STUDY AREAS}

The analyses of the flora and vegetation were performed in south-eastern Poland in the Sandomierz Basin, in four typical agricultural villages: Koszyce Małe, Kolbuszowa Dolna, Roźwienica, and Krzeczowice. The choice of the study areas was dictated by the distinct and varied human impact on the plant cover.

Koszyce Małe is a small village situated ca. $6 \mathrm{~km}$ away from Tarnów with an evident process of land urbanization. The village is located in the near Carpathians part of the Sandomierz Basin in the Biała River valley. According to the geomorphological division proposed by StaRkel (1972), it lies on the Wojnicz Plateau within the Bochnia Foothills mesoregion (KondRACKI 2009). The Wojnicz Plateau is built of Miocene formations covered by Quaternary sediments - loess and gravel deposited by the river. The climate of the region is characteristic for the mesoclimates of plateaus and higher river terraces. Agricultural land in Koszyce Małe accounts for $80 \%$ of the area. Unmanaged fields and meadows have been converted into building plots.

Kolbuszowa Dolna is situated ca. $3 \mathrm{~km}$ away from Kolbuszowa town in the Nil River valley on the Kolbuszowa Plateau (KonDRACKi 2009). Two transport routes and a newly renovated railway line cross the village. River reclamation has been carried out here. It involved regulation of the riverbed by deepening thereof as well as reinforcement of its banks. The village is characterised by undulating terrain; the bedrock is formed by Miocene clays covered by Quaternary deposits: gravels and sands. It used to be a vast agricultural area, but currently arable land constitutes $60 \%$ of the area, half of which are fallow fields. Unmowed meadows are undergoing the succession process.

Roźwienica is situated $10 \mathrm{~km}$ away from Jarosław in the Mleczka River valley, the Rzeszów Foothills mesoregion (KONDRACKI 2009). Given the favourable agronomic conditions (fertile soils: chernozems and brown soils), the area has been characterised by intense agricultural activity since the 14th century. Since then, natural and seminatural habitats have been transformed and replaced by farmland. Currently, the fields and meadows have mostly been abandoned. Numerous roads, roadside embankments, and reclaimed landfill and a brickyard colonized by synanthropic vegetation are specific ruderal habitats. On the reclaimed land, two water reservoirs were constructed and their banks were planted with woody vegetation. The forest belonging to the village has only retained its natural character.
Similar to Roźwienica, Krzeczowice is a village located in the Mleczka River valley in the Rzeszów Foothills mesoregion, $5 \mathrm{~km}$ away from Kańczuga town (KonDRACKI 2009). The deforested and hilly area is characterised by a monotonous landscape of vast fields. Owing to the favourable agronomic conditions, i.e. fertile chernozems and brown soils, as well as good thermal and moisture conditions, the area is famous for cultivation of sugar beet, cereals, and onion (RABCZAK 2004).

Various forms of the human impact on the vegetation cover were noted in the presented villages. In Koszyce Małe, transformation of fields and meadows into building land was evident. In Kolbuszowa Dolna, intensive changes in land use, abandonment of fields and meadows, and regulation of the Nil River were noted. In Roźwienica, new habitats for plant colonization have emerged after reclamation of land previously occupied by a brick factory and a landfill. Synanthropic plants are colonising abandoned fields and meadows, as well as the surroundings of the constructed water reservoirs. In Krzeczowice, dominance of intensively cultivated fields and long-term unchanged land use were observed.

\section{MATERIAL AND METHODS}

In the areas described above, floristic investigations with the patrol method were carried out in 20092010 consisting in recording plant species growing on roadsides, ditches, meadows, fields, wastelands, railway tracks, and in fragments of natural communities. In 2011-2014, the investigations were supplemented and verified. The historical-geographical classification of the flora species was based on literature data and comprehensive studies of the history species spread (Kornaś 1968, 1981, ZająC 1979, MireK 1981, ZajĄC and ZająC 1992, 2011, ZajĄC et al. 1998, ToKARSKA-GUZIK 2005) as well as own observations. The analysis of the floras was based on indices proposed by KoRNAś (1977) and JACKOWIAK (1990).

Additionally, phytosociological relevés of vegetation patches characteristic of the area were taken with the Braun-Blanquet (1964) method. The classification of vegetation follows MatuszKiewicz (2004), and the classification of soil is based on the Systematics of Polish soils (SystematYKA... 1989).

\section{RESULTS}

The human impact on the vegetation cover in the study areas was assessed by detailed qualitative and quantitative analysis of the examined flora and description of characteristic and most frequent plant communities. Substantial dominance of synanthropic species over non-synanthropic spontaneophytes was noted in the analysed floras (Table 1, Fig. 1). In the synanthropic species group, the proportion of ap- 
Table 1. Characteristics of the study areas and floras

\begin{tabular}{|c|c|c|c|c|}
\hline Characteristics & Koszyce Małe & Kolbuszowa Dolna & Roźwienica & Krzeczowice \\
\hline Surface area $\left(\mathrm{km}^{2}\right)^{*}$ & 4.90 & 9.27 & 8.68 & 7.80 \\
\hline Population* & 1800 & 2124 & 710 & 989 \\
\hline Number of species & 322 & 312 & 368 & 225 \\
\hline \multicolumn{5}{|l|}{ Spontaneophytes: } \\
\hline Non-synanthropic species & 71 & 82 & 76 & 14 \\
\hline Apophytes & 161 & 124 & 208 & 145 \\
\hline \multicolumn{5}{|l|}{ Anthropophytes: } \\
\hline Archeophytes & 31 & 45 & 42 & 28 \\
\hline Kenophytes & 28 & 37 & 27 & 26 \\
\hline $\begin{array}{l}\text { Cultivated plants (potential ephemero- } \\
\text { phytes and ergasiophygophytes ) }\end{array}$ & 31 & 24 & 15 & 12 \\
\hline
\end{tabular}

Note: * - after the Central Statistical Office (GUS 2011).

ophytes was ca. 3-fold higher than that of anthropophytes (with the exception of Kolbuszowa Dolna). Similarly, archaeophytes slightly dominated over kenophytes (with the exception of the flora in Roźwienica). The flora of Krzeczowice, an area affected by long-term anthropopressure, was by approx. 30\% less abundant than that in the other villages (Table 2 ); it was characterised by the highest synanthropization index $(88.44 \%)$, total apophytization index $(64.44 \%)$, and index of apophytism of spontaneophytes $(91.19 \%)$. In turn, the flora in Kolbuszowa Dolna was richer due to the presence of a wide variety
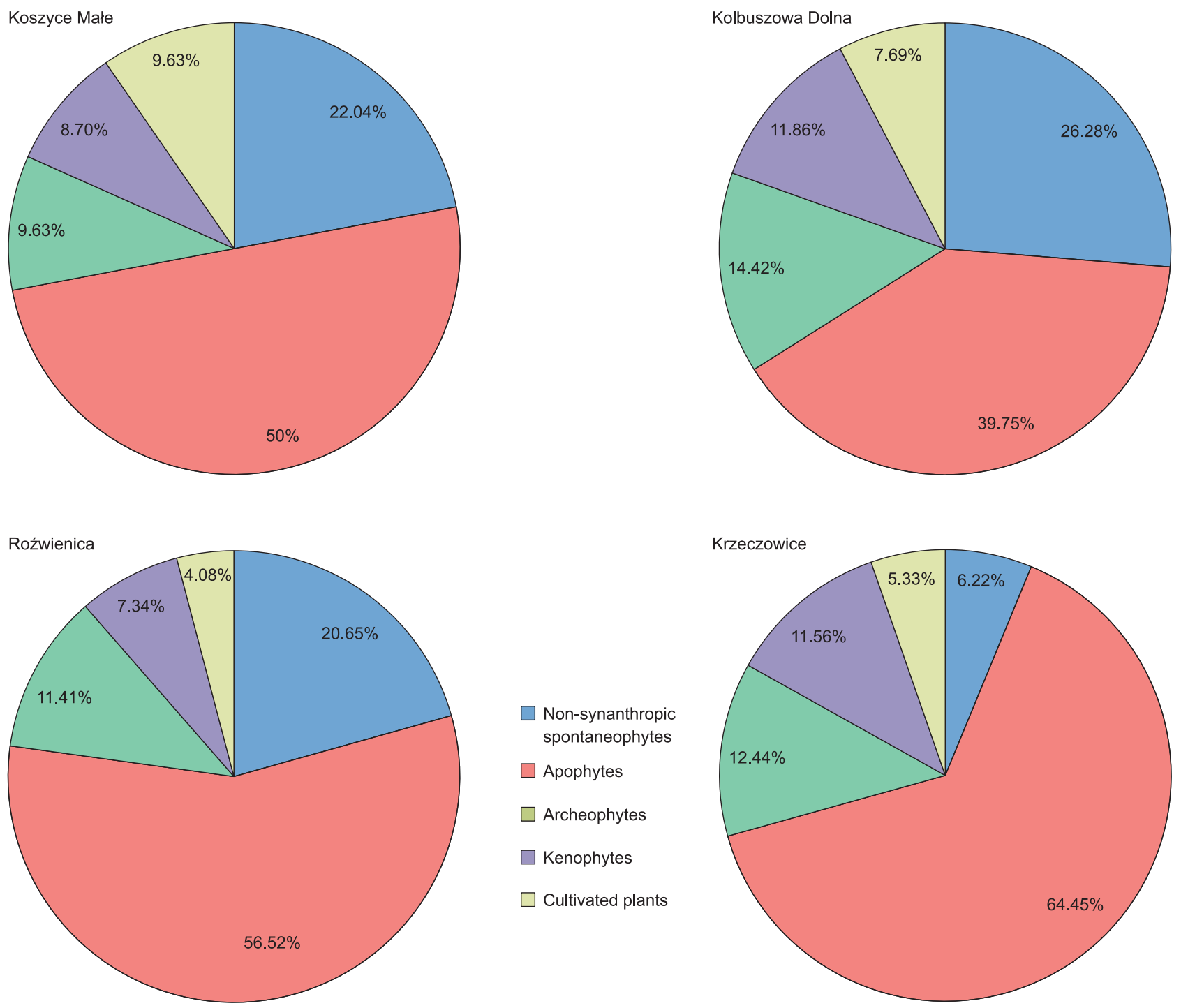

Fig. 1. Spectra of the vascular plant flora in the villages under study 
Table 2. Indices of anthropogenic changes in the flora of the study areas (\%)

\begin{tabular}{lcccc}
\hline \multicolumn{1}{c}{ Index } & Koszyce Małe & Kolbuszowa Dolna & Roźwienica & Krzeczowice \\
\hline Synanthropization index & 68.33 & 66.02 & 75.26 & 88.44 \\
Apophytization index & 50.00 & 39.74 & 56.51 & 64.44 \\
Index of apophytism of spontaneophytes & 69.39 & 60.19 & 73.24 & 91.19 \\
Anthropophization index & 18.33 & 26.28 & 18.75 & 24.00 \\
\hline
\end{tabular}

Table 3. Vegetation of study areas

\begin{tabular}{|c|c|c|c|c|}
\hline Community & Koszyce Małe & Kolbuszowa Dolna & Roźwienica & Krzeczowice \\
\hline $\begin{array}{l}\text { Natural commu- } \\
\text { nities }\end{array}$ & $\begin{array}{l}\text { Molinio caeruleae-Pinetum } \\
\text { (pseudogley soil), } \\
\text { river-side forest of the Alno-Ulmi- } \\
\text { on alliance (gleyed black earth) }\end{array}$ & $\begin{array}{l}\text { river-side forest of the Alnetea } \\
\text { glutinosae class (peat-like gley } \\
\text { soil), Fraxino-Alnetum (gley soil) }\end{array}$ & $\begin{array}{l}\text { Tilio-Carpinetum (cher- } \\
\text { nozem) }\end{array}$ & lack \\
\hline $\begin{array}{l}\text { Semi-natural com- } \\
\text { munities }\end{array}$ & $\begin{array}{l}\text { formerly arable unmowing } \\
\text { meadows from } 2 \text { to } 5 \text { years of } \\
\text { the Arrhenatheretalia order (pseu- } \\
\text { dogley soil), } \\
\text { formerly arable mowing mead- } \\
\text { ows from } 10 \text { years of the Arrhe- } \\
\text { natherion alliance (deluvial soil), } \\
\text { formerly mowing meadows from } \\
2 \text { years of the Arrhenatherion alli- } \\
\text { ance (pseudogley soil), Typhetum } \\
\text { latifoliae (gley soil, peat-like) }\end{array}$ & $\begin{array}{l}\text { Caricetum gracilis (gley soil, } \\
\text { peat-like), community with } \\
\text { Carex hirta (gley soil, peat-like), } \\
\text { Cirsietum rivularis (proper } \\
\text { brown soil), community with } \\
\text { Calamagrostis epigejos (unmow- } \\
\text { ing meadow) }\end{array}$ & $\begin{array}{l}\text { Arrhenatheretum elatioris } \\
\text { (proper brown soil, scarp } \\
\text { of ravine), unmowing Ar- } \\
\text { rhenatheretum elatioris with } \\
\text { domination of Calamagros- } \\
\text { tis epigejos (brown soil, } \\
\text { above discarded working } \\
\text { of brick kiln) }\end{array}$ & $\begin{array}{l}\text { meadow } \\
\text { fragments of } \\
\text { the Molinio- } \\
\text {-Arrhenatheretea } \\
\text { class }\end{array}$ \\
\hline $\begin{array}{l}\text { Synanthropic com- } \\
\text { munities (segetal } \\
\text { communities) }\end{array}$ & $\begin{array}{l}\text { Echinochloo-Setarietum } \\
\text { (stagno-gley soil), } \\
\text { community of the Centauretalia } \\
\text { cyani order (pseudogley soil) }\end{array}$ & $\begin{array}{l}\text { community of the Panico-Seta- } \\
\text { rion (proper rusty soil), } \\
\text { Echinochloo-Setarietum (proper } \\
\text { rusty soil), community with } \\
\text { Calamagrostis epigejos in the } \\
\text { fallow (proper rusty soil) }\end{array}$ & $\begin{array}{l}\text { Artemisio-Tanacetum } \\
\text { (chernozem, fallow), } \\
\text { community of the Poly- } \\
\text { gono-Chenopodietalia order } \\
\text { (proper brown soil) }\end{array}$ & $\begin{array}{l}\text { miserly com- } \\
\text { munities of } \\
\text { the Stellarietea } \\
\text { mediae class }\end{array}$ \\
\hline $\begin{array}{l}\text { Synanthropic com- } \\
\text { munities (ruderal } \\
\text { communities) }\end{array}$ & $\begin{array}{l}\text { community with Solidago gigantea } \\
\text { in fallow (pseudogley soil) }\end{array}$ & $\begin{array}{l}\text { community with Polygonum } \\
\text { aviculare (proper rusty soil, } \\
\text { parking area), community with } \\
\text { Glyceria notata (anthropogenic } \\
\text { soil, riverbank), Artemisio-Tana- } \\
\text { cetum (anthropogenic soil, } \\
\text { earthwork) }\end{array}$ & $\begin{array}{l}\text { Lolio-Polygonetum arenastri } \\
\text { (proper brown soil, dis- } \\
\text { carded working of brick } \\
\text { kiln), cluster of Impatiens } \\
\text { glandulifera (anthropogenic } \\
\text { soil discarded working of } \\
\text { brick kiln), scrub forest } \\
\text { with Salix cinerea (gley soil, } \\
\text { waterbank) }\end{array}$ & $\begin{array}{l}\text { clusters of } \\
\text { Impatiens glan- } \\
\text { dulifera, Calyste- } \\
\text { gia sepium, Rey- } \\
\text { noutria japonica } \\
\text { (anthropogenic } \\
\text { soil) }\end{array}$ \\
\hline
\end{tabular}

of habitats (fragments of natural communities, abandoned fields and meadows, numerous roadsides); it was characterised by the lowest total apophytization index $(39.74 \%)$ accompanied by the highest total anthropophization index $(26.28 \%)$ associated with the greatest abundance of the flora of the roadsides. The substantially higher proportion of non-synanthropic species in the floras of Koszyce Dolne, Kolbuszowa, and Roźwienica than in Krzeczowice was associated with the presence of almost undisturbed forest communities in these locations, which reflects a higher degree of a natural character of the areas. The highest proportion of apophytes (208 species) in the flora of Roźwienica contributing to species richness (the richest flora) was related to colonization of new habitats created by humans through land reclamation. The minor differences between the abundance of archaeophytes and kenophytes in Koszyce Małe and Krzeczowice indicate spread of kenophytes in these areas. A higher proportion of cultivated garden plants, i.e. potential ephemerophytes and ergasiophygophytes, were found in the flora in Koszyce Małe, which is a typical suburban village.
The analysed villages exhibit predominance of anthropogenic semi-natural and synanthropic communities. Natural communities, i.e. small fragments of forests, have remained thanks to the suitable terrain features and substratum. Due to degradation of habitats, they undergo degeneration processes resulting in emergence of phytocoenoses that are difficult to classify. The fields are inhabited by poor segetal communities, whereas ruderal vegetation colonizes wasteland, building sites, roadsides, landfills, and railway tracks. The list of the characteristic and most frequent plant communities of the analysed villages is presented in the Table 3 .

\section{DISCUSSION}

There are few reports from Poland on rural flora similar to available descriptions of urban flora. The process of synanthropization of urban floras, unlike rural areas, has been explored in detail (JACKOWIAK 1998, SuDNIK-WójCIKOWSKA 1998). This may be caused by the differences in the functioning of 
Table 4. Comparison of the synanthropic flora of the presented villages with the flora of adjacent towns in the Sandomierz Basin

\begin{tabular}{|c|c|c|c|c|c|c|c|c|}
\hline \multirow{2}{*}{ Locality } & \multirow{2}{*}{$\begin{array}{l}\text { Surface area } \\
\left(\mathrm{km}^{2}\right)^{*}\end{array}$} & \multirow{2}{*}{$\begin{array}{c}\text { Popula- } \\
\text { tion* }\end{array}$} & \multicolumn{3}{|c|}{ Number of species } & \multicolumn{2}{|c|}{ Value of indices } & \multirow{2}{*}{$\mathrm{K} / \mathrm{Me}$} \\
\hline & & & apophytes & archeophytes & kenophytes & (S) & $(\mathrm{M})$ & \\
\hline Koszyce Małe & 4.60 & 1,802 & 161 & 31 & 28 & 59 & 0.90 & 0.47 \\
\hline Tarnów & 75.38 & 111,830 & - & 43 & 32 & 75 & 0.74 & 0.43 \\
\hline Kolbuszowa Dolna & 9.27 & 2,154 & 124 & 45 & 37 & 82 & 0.82 & 0.45 \\
\hline Kolbuszowa & 7.49 & 9,446 & - & 53 & 72 & 125 & 1.35 & 0.57 \\
\hline Roźwienica & 8.68 & 685 & 208 & 42 & 27 & 69 & 0.64 & 0.39 \\
\hline Krzeczowice & 7.80 & 978 & 145 & 28 & 26 & 54 & 0.92 & 0.48 \\
\hline Jarosław & 34.61 & 39,146 & 328 & 76 & 63 & 139 & 0.82 & 0.45 \\
\hline
\end{tabular}

Notes: S - synanthropisation index, M - modernisation index acc. to KorNAś (1977), K/Me - flora modernisation index acc. to JACKOwIAK (1990), * - after the Central Statistical Office (GUS 2011).

villages and towns. These differences are gradually becoming obliterated and the contemporary village resembles urban districts. FALIŃSKI (1971) was the first to make an attempt at a comparative analysis of urban and rural floras. In turn, WоєKоWYскI (2000a, $2000 \mathrm{~b}$ ) performed a detailed analysis of the flora in built-up areas of four cities, 12 towns, and 23 villages in the southern part of the Nord Podlasie. The results of the investigation of the flora of the Koszyce Małe, Kolbuszowa Dolna, Roźwienica, and Krzeczowice villages are consistent with the model of the trend of variability of synanthropic flora over the series settlements (from a forest settlement to a city) proposed by FALIŃSKI (1971). These floras are characterised by clear dominance of apophytes over anthropophytes and a greater share of archaeophytes than that of kenophytes. This is confirmed by the results obtained by WoŁKowycki (2000a) and Kirpluk (1996, 2009, 2011). KIRPLUK (2011) reports that the floras of 15 abandoned villages of the Kampinoski National Park are dominated by native species - apophytes (two thirds of the flora), and the number of archaeophytes in the individual villages ranges from 28 to 46 species. Similar results were obtained for the four villages analysed in the present study.

Description of flora synanthropization using appropriate indices allows determination of the rate and direction of anthropogenic flora transformations. As proposed by KorNAś (1977), the synanthropization index (a sum of archaeophytes and kenophytes) depends on the size of the analysed area and population and increases with the increasing surface area. This is confirmed by the comparison of the analysed villages (with the exception of Koszyce Dolne) and the extensive and detailed investigations of rural and urban floras conducted by WoŁKOWYCKI (2000a, 2000b).

The floras of nearby cities (Święs \& PIÓRECKI 1986, JUREK 2005, ŻYŁA 2013) in the Sandomierz Basin exhibit a higher flora synanthropization index than that noted in the rural areas (Table 4). The flora modernization index developed by KorNAś (1977), i.e. the ra- tio of kenophytes to archaeophytes in localities situated in areas with similar climatic conditions, should be correlated with the size and specificity of the area. For urban floras, e.g. in Jarosław, the index is higher than that for Roźwienica, but lower than the index for Krzeczowice. Tarnów city bordering Koszyce Małe is 15 -fold larger than the village. As shown by JUREK (2005), the flora of Tarnów comprises 620 species with a proportion of anthropophytes not exceeding that of Koszyce, but the modernization index is lower, likewise the flora modernization index proposed by JАСKOWIAK (1990).

A characteristic feature of the vegetation of Koszyce Małe is the presence of abandoned fields and post-agricultural meadows. Abandonment of land initiates secondary succession. Fallows are colonized by vegetation characteristic for habitats associated with appropriate substrate (pseudogley soil). The first stages of succession involve colonization of fallows by a meadow community of the Arrhenatherion alliance or community with domination Solidago gigantea. Within several years, shrubs, with Prunus pa$d u s$ appearing first, colonize fallow areas. The species composition of the succession stages is different from that reported by Dubiel (1984) and FALIŃSKI (1986). In this case, the processes of vegetation synanthropization should be compared with the ecological succession process. The necessity of interpretation of comtemporary changes in vegetation in accordance with the basics of the synanthropization and syndynamics theory was emphasized by FALIŃski (2001). The author believed that anthropogenic vegetation resulting from the synanthropization process could be the subject of analysis, classification, and description to a limited degree only. Elucidation of the vegetation synanthropization process requires consideration of its relationship with primary vegetation and vegetation liberal of the former anthropopressure. This requires knowledge of ecological processes that have an impact on vegetation. 


\section{CONCLUSIONS}

1. The investigations revealed a clear relationship between human activity and vegetation transformations.

2. Long-term, intensive anthropopressure (observed in Krzeczowice) substantially reduces flora species richness and diversity of plant communities.

3. In contrast, reclamation of previously disturbed land (Kolbuszowa Dolna, Roźwienica) facilitates colonization of new habitats by synanthropic species and increases the flora species richness and the diversity of plant communities.

4. Abandonment of fields and meadows contributes to increased species richness in vegetation patches in the initial stages of succession (Koszyce Małe).

\section{ACKNOWLEDGEMENTS}

The authors wish to thank Prof. Krystyna Towpasz $\mathrm{PhD}$ and Mateusz Wolanin PhD for verification or indication of some taxa and Mieczysław Langer MSc for his help in identification of the soils in the investigated areas.

\section{REFERENCES}

BACIECZKo W., Borcz A. (2014): The synanthropic flora of Człuchów against anthropogenic indexes. Biodiversity Research and Conservation. Supplement 1: 37.

BomanowsKa A., WitosŁawski P. (2008): Seleted aspects of diversity of synanthropic flora in the chosen cities of central Poland. Biodiversity Research and Conservation 9-10: 35-42.

Braun-Blanquet J. (1964): Pflanzensoziologie. Grundzüge der Vegetationskunde 3. Springer Verlag, Wien.

Dubiel E. (1984): Dolina Wierzbanówki: 5. Rozwój roślinności na odłogach. Prace Botaniczne 12: 97-112.

FALIŃSKI J.B. (1971): Flora i roślinność synantropijna wsi i miast - próba analizy porównawczej. Materiały Zakładu Fitosocjologii Stosowanej UW 27: 15-37.

FALIŃSKI J.B. (1986): Sukcesja roślinności na nieużytkach porolnych jako przejaw dynamiki ekosystemu wyzwolonego spod długotrwałej presji antropogenicznej. Wiadomości Botaniczne 30(1): $25-50$.

FALIŃSKI J.B. (2001): Interpretacja współczesnych przemian roślinności na podstawach teorii synantropizacji i syndynamiki. Prace Geograficzne Instytutu Geografii i Przestrzennego Zagospodarowania PAN 179: 31-52.
GUS (2011). Bazy danych lokalnych; http://stat.gov. $\mathrm{pl} / \mathrm{bdl} / \mathrm{app} /$ strona.html?p_name $=$ indeks (access: 27.11.2014)

JACKOWIAK B. (1990): Antropogeniczne przemiany flory roślin naczyniowych Poznania. Wyd. Nauk. UAM, Seria Biologia 42.

JACKOWIAK B. (1998): Struktura przestrzenna flory dużego miasta. Studium metodyczno-problemowe. Prace Zakładu Taksonomii Roślin UAM w Poznaniu 8. Bogucki Wyd. Nauk., Poznań.

Jurek M. (2005): Flora ruderalna wybranych dzielnic miasta Tarnowa: Chyszów, Klikowa, Krzyż, Mościce (Zakłady Azotowe), Piaskówka. Typescript. Praca magisterska wykonana w Zakładzie Taksonomii Roślin i Fitogeografii. Instytut Botaniki Uniwersytetu Jagiellońskiego, Kraków.

KIRPLUK I. (1996): Structure of ruderal florasin abandoned villages in the Kampinos Forest. In: A. Terpo, S. Mochnacky (eds). Anthropization and environment of rural settlements. Flora and vegetation. Proceedings of International Conference, Tarcal-Tokaj, Hungary: 124-133.

KIRPLUK I. (2009): Rośliny dawnych osad i przydroży - flora ruderalna. In: D. Michalska-Hejduk, A. Bomanowska (eds). Rola Kampinoskiego Parku Narodowego w zachowaniu różnorodności biologicznej dawnych terenów wiejskich. Kampinoski Park Narodowy, Izabelin: 67-77.

KiRpluK I. (2011): Najstarsi przybysze we florze ruderalnej opuszczonych wsi Kampinoskiego Parku Narodowego. Acta Botanica Silesiaca 7: 97-112.

KondRACKi J. (2009): Geografia regionalna Polski. Wyd. Nauk. PWN, Warszawa.

Kornaś J. (1968): Geograficzno-historyczna klasyfikacja roślin synantropijnych. Materiały Zakładu Fitosocjologii Stosowanej UW 25: 33-41.

Kornaś J. (1977): Analiza flor synatropijnych. Wiadomości Botaniczne 21: 85-91.

KoRnAś J. (1981): Oddziaływanie człowieka na florę: mechanizmy i konsekwencje. Wiadomości Botaniczne 25(3): 165-182.

Matuszkiewicz W. (2004): Przewodnik do oznaczania zbiorowisk roślinnych Polski. Wyd. Nauk. PWN, Warszawa.

Mirek Z. (1981): Problemy klasyfikacji roślin synantropijnych. Wiadomości Botaniczne 25: 45-54.

RABCZAK S. (2004): Program Ochrony Środowiska. Plan Gospodarki Odpadami dla Miasta i Gminy Kańczuga na lata 2004-2015. Urząd Miasta i Gminy, Kańczuga.

Starkel L. (1972): Karpaty Zewnętrzne. In: M. Klimaszewski (ed.). Geomorfologia Polski. Tom 1. Polska południowa. Góry i wyżyny. PWN, Warszawa: 52-115.

Sudnik-Wójcikowska B. (1998): Czasowe i przestrzenne aspekty procesu synantropizacji flory na przykładzie wybranych miast Europy Środkowej. Wyd. Uniwersytetu Warszawskiego, Warszawa. 
Systematyka gleb Polski (1989) Roczniki Gleboznawcze 40, 3/4: 1-150.

Święs F., PióreCKI J. (1986): Zbiorowiska ruderalne i flora synantropijna w Jarosławiu. Rocznik Przemyski 24/25: 385-410.

TOKARSKA-GuZIK B. (2005): The establishment and spreading of alien plant species (kenophytes) in the flora of Poland. Wyd. Uniwersytetu Śląskiego, Katowice.

Wоєкошүскі D. (1997): Flory ruderalne w krajobrazie wiejskim Niziny Północnopodlaskiej - wstęp do analizy porównawczej. Fragmenta Floristica et Geobotanica - Series Polonica 4: 39-74.

WoŁкоWYскі D. (2000a): Differentiation of ruderal floras in environmental plant in Central Europe. In: B. Jackowiak, W. Żukowski (eds). Mechanism of anthropogenic changes of the plant cover. Publications of the Department of Plant Taxonomy of the Adam Mickiewicz University in Poznan 10. Bogucki Wyd. Nauk., Poznań: 111-124.

WoŁKOWYCKi D. (2000b): Różnicowanie i ujednolicanie się flor ruderalnych $\mathrm{w}$ warunkach izolacji środowiskowej. Monographiae Botanicae 87: 1-157.
ZajĄC A. (1979): Pochodzenie archeofitów występujących w Polsce. Zeszyty Naukowe Uniwersytetu Jagiellońskiego, Rozprawy Habilitacyjne 29.

ZająC A., Zając M., TokarsKa-GuZiK B. (1998): Kenophytes in the flora of Poland: list, status and origin. Phytocoenosis 10. Suplementum Cartographiae Geobotanicae 9: 107-116.

ZAJĄC M., ZAJĄC A. (1992): A tentative list of segetal and ruderal apophytes in Poland. Prace Botaniczne 24: 11-23.

ZająC M., ZajĄC A. (2011): Methodical problems in distinguishing the group of archeophytes. Synantropizacja $\mathrm{w}$ dobie zmian różnorodności biologicznej. Acta Botanica Silesiaca 6: 55-62.

ŻyŁA A. (2013): Flora naczyniowa Kolbuszowej i okolic. Typescript. Praca magisterska wykonana w Zakładzie Botaniki. Wydział Biologiczno-Rolniczy Uniwersytetu Rzeszowskiego, Rzeszów.

For citation: KotaŃSKa M., BuZiak-ChMielowiec E., Dąbrowska A., Gladysz M., Wójcik T. (2015): Human impact on the plant cover of four villages in SE Poland. Steciana 19(2): 115-121. DOI 10.12657/steciana.019.013 